\title{
Primary Degenerative Dementia Without Alzheimer Pathology
}

\author{
Arthur W. Clark, Charles L. White III, Herbert J. Manz, Irma M. Parhad, \\ Bernadette Curry, Peter J. Whitehouse, John Lehmann, and Joseph T. Coyle
}

\begin{abstract}
To define the pathology in cases of non-Alzheimer primary degenerative dementia (non-AD PDD), we have studied autopsies from four medical centres accessioned in consecutive years since 1976. Neurochemical studies of the basal forebrain-cortical (BF-C) cholinergic system have been conducted in cases from which frozen tissue was available. Twenty-two cases (mean age 70 years, range 47-86) in which the history was consistent with PDD, but which did not meet anatomic criteria for AD, were selected. Approximately 70 cases of PDD, which were accessioned in the same years and met the anatomic criteria for $A D$, were excluded. The pathologic findings permitted a classification into six groups: Lewy body disease (LBD), 4 cases; Pick's disease, 6 cases; cortical degeneration with motor neuron disease (CDmnd), 2 cases; hippocampal and temporal lobe sclerosis, 3 cases; few or nonspecific abnormalities, 5 cases; other disorders, 2 cases. Our findings suggest that LBD and Pick's disease account for a large proportion of cases of non-AD PDD in the presenile age group, but that a large number of other disorders occasionally present as PDD. Careful examination of the motor systems, as well as cerebral structures relate ${ }^{\prime}$ to cognitive function, is important in the neuropathologic evaluation. Lesions of the BF-C cholinergic system have been most consistent and severe in LBD, and have not been identified in CDmnd.
\end{abstract}

RÉSUMÉ: La démence primaire d'origine dégénérative sans les caractéristiques pathologiques de la maladie d'Alzheimer. Nous avons étudié du matériel d'autopsies accumulé depuis 1974, provenant de quatre centres médicaux, afin de préciser la pathologie chez les cas de démence primaire d'origine dégénérative de type non-Alzheimer (DPD non-MA). Nous avons procédé à des études neurochimiques du système cholinergique du cortex de la face inférieure du prosencéphale (C-IP) chez les cas pour lesquels du tissu congelé était disponible. Nous avons choisi 22 cas (âge moyen 70 ans, écart 47-86) qui avaient une histoire compatible avec une DPD, mais qui ne correspondaient pas aux critères anatomiques de la MA. Nous avons exclu à peu près 70 cas de DPD, accumulés au cours des mêmes années et qui rencontraient les critères anatomiques de la MA. Les constatations pathologiques nous ont permis de classifier ces cas en six groupes: la maladie à corps de Lewy (MCL), 4 cas; la maladie de Pick, 6 cas; la dégénérescence corticale avec maladie du neurone moteur (DC $\mathrm{mnm}$ ), 2 cas; la sclérose de l'hippocampe et du lobe frontal, 3 cas; peu d'anomalies ou des anomalies non spécifiques, 5 cas; d'autres affections, 2 cas. Ces observations nous autorisent à penser que la MCL et la maladie de Pick sont responsables d'une grande partie des cas de DPD non-MA chez les patients qui sont dans le groupe d'âge pré-sénile, mais que une grand nombre d'autres affections se présentent occasionnellement comme la DPD. Il est important d'examiner attentivement les systèmes moteurs ainsi que les structures cérébrales en rapport avec les fonctions cognitives lors de l'évaluation du système cholinergique du C-IP, qui sont les plus constantes et les plus sévères. Ces lésions sont absentes dans la (DC $\mathrm{mmm})$.

Can. J. Neurol. Sci. 1986; 13:462-470

Alzheimer's disease (AD) is a common cause of dementia in middle and later life. The term primary degenerative dementia (PDD) has been used as a synonym for AD in clinical practice.' Clinical evaluation using established criteria for PDD can detect AD with a specificity of more than $80 \%, 2.3$ and this percentage can probably be increased by choosing even more restrictive criteria for AD. ${ }^{4}$

Despite this reassuring record of clinical diagnosis, there are numerous cases of PDD which do not have the pathologic features of $A D$ at biopsy ${ }^{5.6 .7}$ or autopsy. ${ }^{2.3 .7 .8}$ The clinician or the pathologist confronted with such cases may have difficulty in choosing further studies, because there has been no satisfactory classification of PDD without Alzheimer pathology. This deficiency has also impeded application of basic research strategies used in AD.

In an effort to define the spectrum of non-AD PDD, we conducted a study of autopsies in which the history was consistent with PDD. The cases which did not meet pathologic cri-

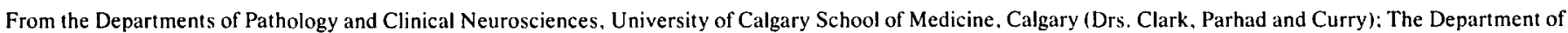
Pathology. Southwestern Medical School, Dallas, Texas (Dr. White); The Departments of Pathology and Neurology, Georgetown University School of Medicine. Washington, D.C. (Dr. Manz); the Departments of Neurology and Neuroscience, John Hopkins University School of Medicine, Baltimore, Maryland (Dr. Whitehouse); the Department of Neurosciences, CIBA-GEIGY Corporation. Summit. New Jersey (Dr. Lehmann) and the Departments of Psychiatry. Neurosciences. Pharmacology and Pediatrics, John Hopkins University School of Medicine, Baltimore, Maryland (Dr. Coyle)

Reprint requests to: Dr. Arthur Clark. Department of Pathology, Ilth Floor, Foothills Hospital, 1403 - 29th Street N.W., Calgary. Alberta, Canada T2N 2T9 
teria for $\mathrm{AD}$ could be classified on the basis of neuropathologic features. Because these cases resembled AD clinically, and because lesions of the basal forebrain-cortical (BF-C) cholinergic system are believed to play a major role in the neuropsychologic deficits of $\mathrm{AD}$, we have studied chemical and anatomic aspects of this system in cases from which appropriate material was available.

\section{Materials AND Methods}

Autopsy material from four medical centres, accessioned in consecutive years since 1976, served as the source of the case material. Cases were selected for study only if the clinical records indicated the presence of dementia consistent with PDD. Anatomic and chemical methods have been previously described. ${ }^{9.10 .11 .12}$ The silver stains used (Bielschowsky, Naoumenko-Feigin, Sevier-Munger, and Bodian) were those in routine use by the participating laboratories for detection of NP and NFT. All cases selected had fewer than seven NP per $\mathrm{mm}^{2}$ of neocortex, NFT were identified in the hippocampus of a few cases in groups $\mathrm{I}$ and $\mathrm{V}$, but were rare in neocortex.

\section{RESUlTS}

Twenty-two cases of PDD which did not meet anatomic criteria for Alzheimer's disease were identified and were classi- fied according to the neuropathologic findings (groups I-VI). Approximately 70 cases which met anatomic criteria for AD, and which were identified in the autopsy material accessioned during the same years, were excluded from this study.

\section{Group I. Lewy Body Disease}

Clinical and pathological data on these four cases are shown in Tables IA and IB. Moderate numbers of NP were present in case $\mathrm{I}-1$, but these were rare in the other three cases (Table 1B). Lewy bodies were numerous in the usual subcortical sites of all these cases.

In cases $\mathrm{I}-1$ and $\mathrm{I}-2$, our anatomic and chemical findings indicate severe damage to the $\mathrm{BF}-\mathrm{C}$ cholinergic system. Maximum population density of neurons in the midportion of the NBM, expressed as neurons $/ \mathrm{mm}^{2}$, were approximately a third those of controls (case I-1, $54 \pm 8$; case I-2, $58 \pm 8$; controls, 167 \pm 29 ; all values expressed as mean \pm SEM). Choline acetyltransferase (CAT) activity in neocortex was about one fifth that of controls (case I-1, $1.02 \pm 0.22$; case $1-2,0.97 \pm 0.08$; controls, $5.35 \pm 1.40 \mathrm{nmol} / \mathrm{mg}$ protein $/ \mathrm{hr}$, all values expressed as mean \pm SEM). ${ }^{13}$

\section{Group II. Pick's Disease}

We have subdivided these cases to correspond to groups $A$, B, and Cof Constantinidis et al. (14; Tables 2A, 2B). In variant A,

Table 1: Lewy Body Disease

A. Clinical Data

\begin{tabular}{lccccc}
\hline Case Number & Age (yrs) & Sex & $\begin{array}{c}\text { Duration of } \\
\text { Dementia (yrs) }\end{array}$ & $\begin{array}{c}\text { Clinical } \\
\text { Diagnosis }\end{array}$ & Other Clinical Data \\
\hline $\mathrm{I}-1$ & $55^{*}$ & $\mathrm{~F}$ & (chronic) & AD & $\begin{array}{l}\text { severe, progressive dementia } \\
\text { Early difficulty following directions and dressing } \\
\text { h-2 }\end{array}$ \\
73 & F & 7 & AD & $\begin{array}{l}\text { diffusely abnormal EEG; mild tremor, shuffling gait, } \\
\text { rigidity, grasp reflexes. }\end{array}$ \\
$\mathrm{I}-3$ & 63 & $\mathrm{M}$ & 20 & AD & Transient delirium; fluctuating behavioral \\
$\mathrm{I}-4$ & 79 & $\mathrm{M}$ & 5 & AD & $\begin{array}{l}\text { aberrations; subsequent loss of ability to provide } \\
\text { for himself; diffusely abnormal EEG; CT: mild } \\
\text { atrophy, left parietal "infarct". }\end{array}$ \\
\hline
\end{tabular}

*approximate age

Table 1: Lewy Body Disease

B. Pathological Data

\begin{tabular}{|c|c|c|c|}
\hline $\begin{array}{c}\begin{array}{c}\text { Case } \\
\text { Number }\end{array} \\
\end{array}$ & $\begin{array}{c}\text { Brain Wt } \\
\text { (grams) }\end{array}$ & Gross Findings & Microscopic Findings \\
\hline $1-1$ & 1060 & Moderate cortical atrophy & $\begin{array}{l}4 \mathrm{NP} / \mathrm{mm}^{2} \text { of neocortex. NFT rare in neocortex; moderate } \\
\text { number of NFT in hippocampus. Lewy body-like inclusions } \\
\text { frequent in cortex: Lewy bodies in some remaining cells of NBM. }\end{array}$ \\
\hline $1-2$ & 1180 & Moderate cortical atrophy & $\begin{array}{l}\text { Fewer than I NP/mm } \mathrm{mm}^{2} \text { of neocortex; no NFT in neocortex, } \\
\text { small number in hippocampus. Moderate number of Lewy } \\
\text { body-like inclusions in neocortex. Lewy bodies in some remaining } \\
\text { cells of NBM. }\end{array}$ \\
\hline I-4 & 1255 & $\begin{array}{l}\text { Atrophy of the anterior } \\
\text { third of superior temporal } \\
\text { gyrus. No grossly apparent } \\
\text { infarction. Acute meningitis } \\
\text { and multiple small brain } \\
\text { abscesses. }\end{array}$ & $\begin{array}{l}\text { No NP or NFT in neocortex. Rare NFT in hippocampus. Frequent Lewy } \\
\text { body-like inclusions in neocortex. Lewy bodies and moderate cell } \\
\text { loss in NBM. }\end{array}$ \\
\hline
\end{tabular}


both Pick bodies and swollen chromatolytic neurons (SCN) were identified; in variant $B$, there were SCN but no Pick bodies. In our one case of variant C (IIc-1), where neither Pick bodies nor SCN were identified, the sharply circumscribed frontal atrophy (Figure 1), and a distribution of subcortical lesions similar to that in case Ila-3, led to its inclusion as a case of Pick's disease.

Studies of neocortical CAT in case IIb- 1 and of representative sections of the NBM in cases IIb- 1 and IIb-2 revealed no lesions of the BF-C cholinergic system. ${ }^{9}$ In case IIa-2, representative sections of the NBM showed no difference from normal controls.
Group III. Cortical Degeneration with Motor Neuron Disease (CDmnd)

Clinical and pathological data are shown in Tables $3 \mathrm{~A}$ and 3B. In neither case could we identify lesions of the BF-C cholinergic system. CAT activity in neocortex of case III-I was $3.78 \pm 0.92 \mathrm{nmol} / \mathrm{mg}$ protein $/ \mathrm{hr}$ (Controls, $3.89 \pm 0.93$, mean \pm SEM). Cell counts in the NBM were normal. ${ }^{15}$

\section{Group IV. Hippocampal and Temporal Lobe Sclerosis}

In case IV-1, loss of pyramidal cells from the hippocampus was marked, while lesions in neocortex were less severe. In cases IV-2 and IV-3, the relative severity was reversed, with

Table 2: Pick's Disease

A. Clinical Data

\begin{tabular}{|c|c|c|c|c|c|}
\hline Case number & Age (yrs) & Sex & $\begin{array}{c}\text { Duration of } \\
\text { Dementia (yrs) }\end{array}$ & Clinical Diagnosis & Other Clinical Data \\
\hline IIa-I & 69 & $F$ & 15 & $\begin{array}{l}\text { Chronic organic brain } \\
\text { syndrome }\end{array}$ & $\begin{array}{l}\text { Decorticate posturing terminally; in } \\
\text { nursing home for several years. }\end{array}$ \\
\hline Ila-2 & 78 & $\mathbf{M}$ & 11 & $\begin{array}{l}\text { Chronic organic brain } \\
\text { syndrome due to } \\
\text { cerebral athero- } \\
\text { sclerosis. }\end{array}$ & \\
\hline $\mathrm{IIa}-3$ & 69 & $F$ & 7 & $\mathrm{AD}$ & $\begin{array}{l}\text { Memory loss, repetition of statements, } \\
\text { impaired comprehension, impaired ability } \\
\text { to carry out housework, disinhibited } \\
\text { social behaviour, anomia, disorientation } \\
\text { to place. }\end{array}$ \\
\hline IIb-I & 63 & $\mathbf{M}$ & 4 & $\mathrm{AD}$ & $\begin{array}{l}\text { Personality changes; rapid onset of } \\
\text { impaired speech and comprehension; } \\
\text { marked disorientation (Reference 9). }\end{array}$ \\
\hline Ilb-2 & 72 & $\mathrm{~F}$ & 7 & $\mathrm{AD}$ & $\begin{array}{l}\text { Memory loss, bizarre behaviour, } \\
\text { dysphasia (Reference } 9 \text { ). }\end{array}$ \\
\hline IIc-1 & 64 & $\mathbf{M}$ & 11 & $\mathrm{AD}$ & $\begin{array}{l}\text { Occasional disorientation, impaired } \\
\text { problem solving; memory loss; } \\
\text { inappropriate social behaviour; persever- } \\
\text { ation of speech, dysphasia; marked } \\
\text { disorientation; loss of ability to } \\
\text { recognize family members. }\end{array}$ \\
\hline
\end{tabular}

Table 2: Pick's Disease

B. Pathological Data

\begin{tabular}{|c|c|c|c|}
\hline $\begin{array}{c}\text { Case } \\
\text { Number }\end{array}$ & $\begin{array}{c}\text { Brain Wt } \\
\text { (grams) }\end{array}$ & Gross Findings & Microscopic Findings \\
\hline Ila-1 & 1080 & $\begin{array}{l}\text { Profound temporal lobe } \\
\text { atrophy, less severe } \\
\text { frontal atrophy }\end{array}$ & $\begin{array}{l}\text { No NP or NFT. Numerous Pick bodies in granule cells of dentate } \\
\text { gyrus and pyramidal cells of hippocampus, numerous SCN in } \\
\text { neocortex, extensive cell loss and gliosis in cortex. }\end{array}$ \\
\hline Ila-2 & 825 & $\begin{array}{l}\text { Marked frontal and } \\
\text { temporal gyral atrophy. } \\
\text { Marked enlargement of } \\
\text { ventricles. }\end{array}$ & $\begin{array}{l}3 \mathrm{NP} / \mathrm{mm}^{2} \text { of parietal and occipital neocortex only; no NFT; } \\
\text { No NP or NFT in hippocampus. Pick bodies in dentate granule } \\
\text { cells, hippocampal pyramidal cells, and cells of neocortex. } \\
\text { Gliosis in frontal white matter. No apparent cell loss in NBM. }\end{array}$ \\
\hline 1la-3 & 945 & $\begin{array}{l}\text { Sharply circumscribed } \\
\text { frontal atrophy. }\end{array}$ & $\begin{array}{l}3 \mathrm{NP} / \mathrm{mm}^{2} \text {. Numerous Pick bodies and } \mathrm{SCN} \text { in neocortex; severe } \\
\text { cell loss in substantia nigra; gliosis and cell loss in } \\
\text { neostriatum. }\end{array}$ \\
\hline IIb-1 & 1300 & Moderate frontal atrophy & Cortical degeneration with numerous SCN. (Reference 9) \\
\hline IIb-2 & 1070 & $\begin{array}{l}\text { Moderate frontal atrophy, } \\
\text { slight superior temporal } \\
\text { atrophy. }\end{array}$ & Cortical degeneration with numerous SCN. (Reference 9) \\
\hline IIc-1 & 1248 & $\begin{array}{l}\text { Sharply circumscribed } \\
\text { frontal atrophy } \\
\text { (Figure 1). }\end{array}$ & $\begin{array}{l}\text { Fewer than } 1 \mathrm{NP} / \mathrm{mm}^{2} \text { of neocortex; NFT rare. Cortical } \\
\text { degeneration less than expected from extent of gross atrophy. } \\
\text { Severe cell loss in substantia nigra, gliosis in neostriatum. }\end{array}$ \\
\hline
\end{tabular}


hippocampal damage less severe than the lesions of temporal cortex (Tables 4A and 4B). The possibility that IV-2 and IV-3 represent cases of Pick's disease is discussed below.

\section{Group V. Few or Nonspecific Findings}

Clinical and pathological data are shown in Table 5. The cases in this group were on the average older at the time of death $(80$ \pm 4 years, mean \pm SEM $)$ than cases in the other groups $(67 \pm 8$ years).

\section{Group VI. Other Disorders}

Two different disorders are included in this group (Table 6). Multiple small infarcts associated with subcortical demyelination and axonal loss, and moderate loss of neurons from the NBM, were identified in case VI-1. In case VI-2, severe degeneration of subcortical white matter, descending motor pathways, thalamus, and other subcortical nuclei, were salient features; no infarcts were identified.

\section{Discussion}

In the cases of this report, the extent of Alzheimer-type degeneration was insufficient to account for the dementia. In all cases except those of group V, another form of CNS degeneration was prominent, and appeared to have played a major role in the cognitive dysfunction.

A retrospective study of autopsy material has certain limitations. Clinico-anatomic correlations cannot be as precise as in prospective studies. ${ }^{2.3}$ In the present series, the clinical diagnoses rendered did not make explicit reference to a uniform set of criteria for PDD. Nonetheless, our results suggest that the standards of clinical evaluation in these cases were appropriate. The lesions we identified were those of chronic CNS degeneration, in most cases likely to be indistinguishable from $\mathrm{AD}$ on clinical grounds. A comparison of our findings with previous reports provides additional insight into this problem.

\section{Lewy Body Disease}

The term "Lewy body disease" (LBD) ${ }^{16}$ encompasses most cases of idiopathic Parkinson's disease, but uses a pathologic feature rather than a clinical syndrome as the basis for the designation. Since many of these cases present with mental

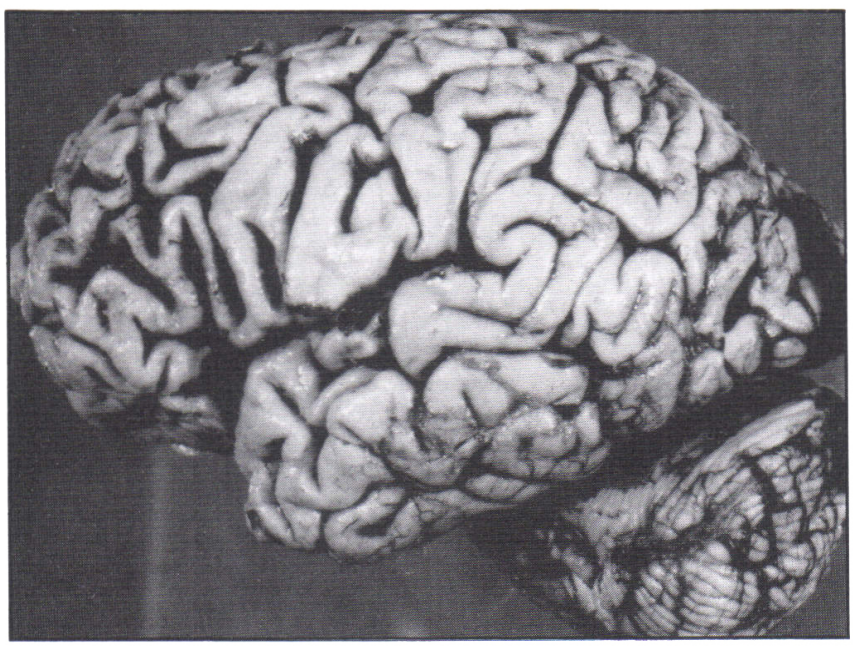

Figure I - Sharply circumscribed frontal atrophy in case IIC-I. disturbance rather than Parkinsonism as the dominant clinical manifestation, ${ }^{2.3 .17-20}$ use of the term LBD has certain advantages. Cortical Lewy body-like inclusions are found in a minority of cases, all of which also have classic Lewy bodies in the usual subcortical sites. The cortical inclusion bodies may thus represent trans-synaptic degeneration consequent to loss of subcortical input. ${ }^{21}$

Previous pathologic studies ${ }^{22.23}$ have emphasized the coexistence of Alzheimer-type neuropathologic changes in the brains of patients with LBD. While some overlap between LBD and $A D$ does exist, ${ }^{17.22-25}$ it is equally clear that dementia is present in some cases of LBD with very few NP or NFT. ${ }^{2,3.20 .25 .27-29,}$ present cases

Lesions of the BF-C cholinergic system are characteristic of

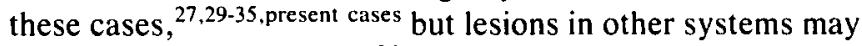
contribute to the dementia. ${ }^{36}$ In some LBD cases, BF-C cholinergic system lesions occur with very few NP or NFT ${ }^{25,27,29,}$ 32,37,present cases The lack of correlation between BF-C cholinergic lesions and AD type pathology is illustrated by our cases I-I and I-2. Severe loss of cortical CAT activity and depletion of NBM neurons in each case was associated with moderate numbers of neocortical plaques in the first case and virtually none in the second.

\section{Pick's Disease}

The difficulty of distinguishing AD from Pick's disease on clinical grounds is well known. ${ }^{38}$ Large autopsy series of Pick's disease cases have been published. ${ }^{14.39} \mathrm{We}$ include in this series a case (IIc-1) without Pick bodies or SCN, similar to the group $C$ cases of a previous report. ${ }^{14}$ The sharply circumscribed atrophy of frontal cortex in this case corresponds to Pick's lobar atrophy; and the involvement of subcortical nuclei closely resembled that in case Ila-3. Retention of such cases as a variant of Pick's disease both favors simplicity and emphasizes important distinctions. The pathological diagnosis of such cases remains problematic, however, ${ }^{9.40}$ much like the diagnosis of "Creutzfeldt-Jakob disease" and related entities prior to 1960.

There are reports describing involvement of the BF-C cholinergic system in Pick's disease, ${ }^{41.42}$ and others in which this system was studied and no significant loss of NBM neurons or CAT activity in cortex was identified. ${ }^{7,43-46}$,present cases 1la-2. Ilb-1.Ilb-2 This variability from case to case may be related to the pathogenetic mechanism of cell loss in the NBM. Specifically, the loss of neurons in the basal forebrain in Pick's disease could be a late, retrograde consequence of cortical degeneration, and dependent on duration and severity of cortical involvement for its appearance. Cases of short duration with severe nbM cell loss have been reported, however. ${ }^{41}$ Correlation of chemical and anatomic findings in cortex with cell counts in the NBM of individual cases will help clarify the significance and frequency of BF-C cholinergic system lesions in Pick's disease.

\section{Cortical Degeneration Associated with Motor Neuron Disease (CDmnd)}

Most cases with these features are probably related to amyotrophic lateral sclerosis. ${ }^{47-50}$ Similar cases have been reported as Pick's disease with ALS, ${ }^{51.52}$ Creutzfeldt-Jakob disease, ${ }^{50}$ dementia with amyotrophic lateral sclerosis, ${ }^{47.48}$ a distinct entity of dementia with motor neuron disease, ${ }^{53.54}$ or as unusual 
THE CANADIAN JOURNAL OF NEUROLOGICAL SCIENCES

Table 3: Cortical Degeneration with Motor Neuron Disease

A. Clinical Data

\begin{tabular}{|c|c|c|c|c|c|}
\hline Case Number & Age (yrs) & Sex & $\begin{array}{c}\text { Duration of } \\
\text { Dementia (yrs) }\end{array}$ & $\begin{array}{c}\text { Clinical } \\
\text { Diagnosis }\end{array}$ & Other Clinical Data \\
\hline III-I & 61 & $\mathrm{~F}$ & 5 & $\mathrm{AD}$ & $\begin{array}{l}\text { Personality changes, impaired comprehension, } \\
\text { dysarthria, progressive decrease in speech output, } \\
\text { disorientation to time and place, hyperactive } \\
\text { reflexes and ankle clonus, flexor plantars; later, } \\
\text { stooped, shuffling gait, cogwheel rigidity. }\end{array}$ \\
\hline III-2 & 77 & F & 5 & $\begin{array}{l}\text { (dementia } \\
\text { clinically } \\
\text { consistent } \\
\text { with AD) }\end{array}$ & $\begin{array}{l}\text { Marked memory deficit, flat affect, little } \\
\text { spontaneous speech, inappropriate answers to } \\
\text { questions, hyperactive reflexes; progression to } \\
\text { mutism and total supportive care. }\end{array}$ \\
\hline
\end{tabular}

Table 3: Cortical Degeneration with Motor Neuron Disease

B. Pathological Data

\begin{tabular}{|c|c|c|c|}
\hline $\begin{array}{c}\text { Case } \\
\text { Number }\end{array}$ & $\begin{array}{l}\text { Brain Wt } \\
\text { (grams) }\end{array}$ & Gross Findings & Microscopic Findings \\
\hline III-1 & 1100 & Moderate frontal atrophy & $\begin{array}{l}\text { No NP or NFT. Cortical neuron loss and rarefaction; cell loss and } \\
\text { gliosis in dorsal caudate and substantia nigra; degeneration of } \\
\text { lateral corticospinal tracts, loss of anterior horn cells; numerous } \\
\text { Bunina body-type inclusions in motor neurons of spinal anterior } \\
\text { horn and hypoglossal nucleus. }\end{array}$ \\
\hline III-2 & 1190 & $\begin{array}{l}\text { Mild symmetric frontal } \\
\text { lobe atrophy }\end{array}$ & $\begin{array}{l}\text { Severe cortical degeneration, with neuronal loss and gliosis; severe } \\
\text { amyloid angiopathy; fewer than } 1 \mathrm{NP} / \mathrm{mm}^{2} \text { of cortex, NFT very rare } \\
\text { in neocortex and hippocampus; loss of motor neurons, with occasional } \\
\text { Bunina bodies and increased number of large axonal swellings in } \\
\text { spinal anterior horns. }\end{array}$ \\
\hline
\end{tabular}

Table 4: Hippocampal and Temporal Lobe Sclerosis

A. Clinical Data

\begin{tabular}{|c|c|c|c|c|c|}
\hline Case Number & Age (yrs) & Sex & $\begin{array}{c}\text { Duration of } \\
\text { Dementia (yrs) }\end{array}$ & $\begin{array}{c}\text { Clinical } \\
\text { Diagnosis }\end{array}$ & Other Clinical Data \\
\hline IV-1 & 72 & $\mathrm{~F}$ & 6 & $A D$ & $\begin{array}{l}\text { Occasional disorientation downtown, memory loss, } \\
\text { word-finding difficulty, slurred speech, confusion, } \\
\text { nursing home placement } 15 \text { months before death. }\end{array}$ \\
\hline IV-2 & 64 & $\mathbf{M}$ & 8 & $A D$ & $\begin{array}{l}\text { Behaviour changes, loss of recent memory; no focal } \\
\text { neurologic deficits; progressively unmanageable } \\
\text { behaviour led to nursing home placement } 6 \text { months before } \\
\text { death. }\end{array}$ \\
\hline
\end{tabular}

Table 4: Hippocampal and Temporal Lobe Sclerosis

B. Pathological Data

\begin{tabular}{|c|c|c|c|}
\hline $\begin{array}{c}\text { Case } \\
\text { Number }\end{array}$ & $\begin{array}{c}\text { Brain Wt } \\
\text { (grams) }\end{array}$ & Gross Findings & Microscopic Findings \\
\hline
\end{tabular}

IV-I $1100 \quad$ Minimal atherosclerosis, obvious cortical atrophy, shrunken and discolored mammillary bodies.

IV-2 $1200 \quad$ Minimal atherosclerosis severe temporal and moderate frontal lobe atrophy.

IV-3 $\quad 1020 \quad$ No atherosclerosis, generalized atrophy, most marked in frontal and temporal regions; enlargement of ventricular system, most pronounced in temporal horn. 
cases of dementia in which pathologic involvement of the motor neurons is discovered at autopsy. ${ }^{55} \mathrm{~A}$ common pathogenesis and etiology may unite many of them. Their existence emphasizes the importance of carefully examining the motor system in cases of PDD. Data on the motor systems in classic Pick's disease and variants would help clarify the interface between Pick's disease and CDmnd.

Damage to cholinergic motor neurons is a hallmark of these cases. In contrast, no lesions of the BF-C cholinergic system have been identified ${ }^{49.56}$ findings in accord with our data. Thus the available evidence suggests that lesions of the BF-C cholinergic system do not play a significant role in the dementia of CDmnd.

Extensive amyloid angiopathy like that in case III-2 is commonly associated with NP, but the numbers are often small. ${ }^{57.58}$ The rarity of NFT and NP in our case excluded the diagnosis of AD. The diffuse cortical degeneration and the dementia were more likely related to the neurodegenerative process than to the amyloid angiopathy, although a contribution of the latter is difficult to exclude.

\section{Hippocampal and Temporal Lobe Sclerosis}

At least seven such cases have now appeared in reports on PDD, 2.3.present cases but it is not clear that these cases represent a distinct entity. Preferential damage to amygdala, hippocampus, and temporal cortex can result from various disorders, and occasional cases of each might present as PDD. Disorders other than AD which can preferentially affect these structures include Pick's disease, limbic encephalitis, herpes simplex encephalitis, and ischemia.

In two of our three cases (IV-2 and IV-3), a preferential atrophy of anterior temporal and frontal regions suggested the possibility of Pick's disease on gross examination. Lesions of the hippocampus in these two cases were much less extensive than those of temporal neocortex. This order of severity is identical to that observed by Constantinidis in the Pick's disease cases of group $C$ with atrophy predominantly in the temporal region; he noted that the hippocampus was routinely "spared" in these cases. ${ }^{14}$ We did not classify cases IV-2 and IV-3 as Pick's disease because we could not document either a circumscribed lobar atrophy or the SCN or Pick bodies of that disorder.

Table 5: Few or Nonspecific Abnormalities

\begin{tabular}{|c|c|c|}
\hline $\begin{array}{c}\text { Case } \\
\text { Number }\end{array}$ & Clinical Data & Pathological Data \\
\hline $\mathrm{V}-1$ & $\begin{array}{l}74 \text { year old man, } 10 \text { year history } \\
\text { diagnosed "advanced AD". }\end{array}$ & $\begin{array}{l}\text { Brain weight } 1280 \text { grams. Rare NFT, moderate number of NP (Fewer } \\
\text { than } 7 \mathrm{NP} / \mathrm{mm}^{2} \text { of neocortex). }\end{array}$ \\
\hline $\mathrm{V}-2$ & $\begin{array}{l}81 \text { year old woman; organic brain } \\
\text { syndrome for } 10 \text { years; tardive } \\
\text { dyskinesia. }\end{array}$ & $\begin{array}{l}\text { Brain weight } 1225 \text { grams. Recent large left frontal infarct, } \\
\text { older lacunar infarcts. Fewer than } 1 \mathrm{NP} / \mathrm{mm}^{2} \text { of neocortex. } \\
3 \mathrm{NFT} / \mathrm{mm}^{2} \text { in parts of hippocampus; occasional NFT in neocortex. }\end{array}$ \\
\hline $\mathrm{V}-3$ & $\begin{array}{l}77 \text { year old man with more than } 30 \text { year } \\
\text { history of dementia, diagnosed AD. }\end{array}$ & No abnormal findings except very small numbers of NP and NFT. \\
\hline V.5 & 86 year old man with chronic dementia. & $\begin{array}{l}\text { Brain weight } 1300 \text { grams. Sulcal widening, enlarged ventricles. No } \\
\text { focal lesions. Fewer than } 1 \mathrm{NP} / \mathrm{mm}^{2} \text { of cortex. Occasional NFT in } \\
\text { hippocampus. }\end{array}$ \\
\hline
\end{tabular}

Table 6: Other Disorders

\begin{tabular}{|c|c|c|}
\hline VI-1 & $\begin{array}{l}62 \text { year old man, } 6 \text { year history } \\
\text { of dementia, believed to be } \\
\text { AD or Pick's disease; wide- } \\
\text { based gait, ataxia, and urinary } \\
\text { incontinence also developed. }\end{array}$ & $\begin{array}{l}\text { Brain weight } 1210 \text { grams. Moderate cortical atrophy. Lacunar } \\
\text { infarct in thalamus, other small infarcts in cortex. Trans- } \\
\text { synaptic degeneration of both mammillary bodies. Large. } \\
\text { discrete, relatively symmetric zones of subcortical } \\
\text { demyelination with variable axonal loss but without cavitation. } \\
\text { Demyelinated areas resembled plaques of multiple sclerosis in } \\
\text { some areas, notably cerebellum, pons, and spinal cord. Congo } \\
\text { red stains negative for amyloid angiopathy. }\end{array}$ \\
\hline VI-2 & $\begin{array}{l}47 \text { year old man, } 9 \text { year history } \\
\text { of dementia. "Blurred" vision. } \\
\text { Personality change. Impaired } \\
\text { calculations, poor coordination. } \\
\text { Evaluation } 6 \text { years before death } \\
\text { indicated advanced cerebral } \\
\text { cortical atrophy without involve- } \\
\text { ment of cerebellum or basal } \\
\text { ganglia. Shuffling gait, slurred } \\
\text { speech, wheelchair, then bedridden } \\
\text { state with muscle "rigidity" } \\
\text { preceded death. }\end{array}$ & $\begin{array}{l}\text { Cortical biopsy } 6 \text { years before death showed no specific } \\
\text { pathologic change. Brain weight } 1139 \text { grams. Extremely wide } \\
\text { sulci, especially over frontal convexities; markedly } \\
\text { enlarged ventricle; extensive atrophy and discolouration of } \\
\text { subcortical white matter. Severe atrophy of thalamus, } \\
\text { marked atrophy of caudate. Histologically, severe neuronal } \\
\text { loss in several thalamic nuclei, severe degeneration of } \\
\text { subcortical fibres and corticospinal tracts, swelling and } \\
\text { chromatolysis of almost all neurons in nuclei basis pontis. }\end{array}$ \\
\hline
\end{tabular}


Limbic encephalitis may occur in the absence of detectable neoplasia. ${ }^{59}$ Inflammatory cells may be sparse in the residual lesion, with neuronal loss and gliosis involving hippocampus, amygdala, and adjacent neocortex as the dominant neuropathological features. ${ }^{60.61}$ Cortical and subcortical areas outside the limbic system are affected in some cases. ${ }^{61.62} \mathrm{~A}$ number of reports have described cases with hippocampal sclerosis, in which limbic encephalitis was the final diagnosis ${ }^{59.61 .63}$ or was consistent with the data provided in the report ${ }^{60.64}$ Some cases of hippocampal sclerosis, such as our case IV-1, may represent sequelae of limbic encephalitis. The possibility of altered expression of herpes simplex encephalitis should also be considered in these patients; efforts at in situ hybridization may be warranted.

Volpe et $\mathrm{al}^{65}$ have recently reported cases of dementia associated with bilateral medial temporal lobe ischemic lesions. Clinical and pathologic features in our cases did not support an ischemic cause. Atherosclerosis was minimal in the two cases where it was specifically mentioned; there was no clinical or pathologic evidence of significant hypertension; and the distribution of the lesions did not correspond to the territory of a particular vessel.

\section{Few or Nonspecific Findings}

Correlation between morphologic findings and the history of dementia was unsatisfactory in these cases. Small numbers of neuritic plaques, occasional small infarcts, and a few neurofibrillary tangles confined to the hippocampus were characteristic findings. Previous reports have included cases with little apparent pathologic change at autopsy. ${ }^{2,3,7,8}$ The problem arises in a large percentage of biopsied cases. ${ }^{5-7}$

The average age in group $V$ was greater than in other groups of this study. Nonspecific cell loss or other factors difficult to detect with standard microscopic evaluation may have contributed to the cognitive dysfunction. Moreover, we cannot exclude the possibility that depression, systemic illness, or medications played a role in one or more of the cases in this group.

\section{Other}

The first of our cases in this group resembled cases reported by Heffner et al, ${ }^{66}$ but we were unable to document amyloid in cerebral vessels. Mechanisms described by Feigin ${ }^{67}$ may have been of pathogenetic importance. The second case resembles some reported cases of thalamic degeneration, ${ }^{68}$ but the severity of subcortical axonal destruction was distinctive.

These cases and other entities, such as progressive subcortical gliosis,${ }^{69}$ emphasize the difficulty of classifying PDD. Recent reports indicate that occasional cases of progressive supranuclear palsy, ${ }^{70}$ of Creutzfeldt-Jakob disease, ${ }^{71}$ of dementia with HTLVIII/LAV infection of the CNS, ${ }^{72}$ and of neuronal intranuclear hyaline inclusion disease (Munoz-Garcia and Ludwin, present symposium) are difficult to distinguish from $\mathrm{AD}$ on clinical grounds.

\section{Conclusion}

Precision of clinical diagnosis in PDD may improve with use of neuropsychologic testing ${ }^{73}$ chemical studies of the cerebrospinal fluid, ${ }^{74}$ and recent advances in brain imaging. ${ }^{75} \mathrm{~A}$ clearer definition of the anatomic and chemical basis for non-AD PDD will facilitate these efforts. Previous reports relevant to this problem $2.3 .5 .7,17.20 .55 .76-79$ have indicated the importance of LBD, 2,3,17,20.79 Pick's disease, ${ }^{7,76}$ and CDmnd; ${ }^{.5}$ and the existence of cases with hippocampal sclerosis. ${ }^{2.3}$ In the present study, Pick's disease and Lewy body disease were the two major forms of non-AD PDD; but our findings and other reports indicate that a large number of other disorders occasionally present as PDD.

The BF-C cholinergic system is damaged in cases of LBD, and the lesions of this system may be important in the mental disturbances. There is no evidence for damage to this system in CDmnd. In Pick's disease, involvement of the NBM is variable and may occur later in the disease process, possibly as a result of retrograde degeneration following cortical damage.

\section{ACKNOWLEDGEMENTS}

This work was supported in part by a grant from the Alberta Mental Health Advisory Council (Dr. Clark).

\section{REFERENCES}

1. Reisberg B. Clinical presentation, diagnosis, and symptomatology of age-associated cognitive decline and Alzheimer's disease. In: Reisberg B, ed. Alzheimer's Disease: The Standard Reference. New York: The Free Press 1983; 173-187.

2. Sulkava R, Haltia M, Paetau A, et al. Accuracy of clinical diagnosis in primary degenerative dementia: correlation with neuropathologic findings. J Neurol Neurosurg Psychiat 1983; 46: 9-13.

3. Mölsä PK, Paljärvi L, Rinne JO, et al. Validity of clinical diagnosis in dementia: A prospective clinicopathological study. J Neurol Neurosurg Psychiatr 1985; 48: 1085-1090.

4. Fox JH, Penn R, Clasen R, et al. Pathological diagnosis in clinically typical Alzheimer's disease (letter). N Engl J Med 1985; 313 : 1419-1420.

5. Smith WT, Turner E, and Sim M. Cerebral biopsy in the investigation of presenile dementia. II. Pathological aspects. Brit J Psychiat 1966; 112: 127-133.

6. Sims NR, Bowen DM, Smith CCT, et al. Glucose metabolism and acetylcholine synthesis in relation to neuronal activity in Alzheimer's disease. Lancet 1980; 1: 333-335.

7. Bowen DM, Benton JS, Spillane JA, et al. Choline acetyltransferase activity and histopathology of frontal neocortex from biopsies of demented patients. J Neurol Sci 1982; 57: 191-202.

8. Rossor M, Garrett NJ, Johnson AL, et al. A postmortem study of the cholinergic and GABA systems in senile dementia. Brain 1982; 105: 313-330.

9. Clark AW, Manz HJ, White CL III, et al. Cortical degeneration with swollen chromatolytic neurons: Its relationship to Pick's disease. J Neurpathol Exp Neurol 1986; 45: 268-284.

10. Bull G, Oderfeld-Novak B. Standardization of a radiochemical assay of choline acetyltransferase and a study of the activation of the enzyme in rabbit brain. J Neurochem 1971; 18: 935-941.

11. Fonnum F. A rapid radiochemical method for the determination of choline acetyltransferase. J Neurochem 1975; 24: 407-409.

12. Lowry OH, Rosebrough NJ, Farr AL, et al. Protein measurement with the Folin phenol reagent. J Biol Chem 1951; 193: 265-275.

13. Clark AW, Lehmann J. Dementia with widespread Lewy bodies: Studies of the neocortical cholinergic system. (Abstract), Canadian Association of Neuropathologists, 23rd Annual Meeting, Banff, Alberta, September 1983

14. Constantinidis J, Richard J, Tissot R. Pick's disease. Histological and clinical correlations. Europ Neurol 1974; 11: 208-217.

15. Clark AW, Lehmann J, Whitehouse PJ, et al. Cortico-striatospinal degeneration (CSSD) mimicking Alzheimer's disease: Studies of the nucleus basalis of Meynert and cortical choline acetyltransferase. (Abstract) J Neuropathol Exp Neurol 1983; 42: 334 .

16. Yoshimura M. Cortical changes in the Parkinsonian brain: A contribution to the delineation of "diffuse Lewy body disease". J Neurol 1983; 229: 17-32.

17. Woodard JS. Concentric hyaline inclusion body formation in mental disease: Analysis of twenty-seven cases. J Neuropathol Exp Neurol 1962; 21: 442-449. 
18. Forno LS, Barbour PJ, Norville RL. Presenile dementia with Lewy bodies and neurofibrillary tangles. Arch Neurol 1978; 35 818-822.

19. Yagishita S, Itoh Y, Amano N, et al. Atypical senile dementia with widespread Lewy type inclusions in the cerebral cortex. Acta Neuropathol (Berl) 1980; 49: 187-191.

20. Heilig CW, Knopman DS, Mastri AR, et al. Dementia without Alzheimer pathology. Neurology 1985; 35: 762-765.

21. Eggertson DE, Sima AAF. Dementia with cerebral Lewy bodies. A mesocortical dopaminergic defect? Arch Neurol 1986; 43: 524-527.

22. Hakim AM, Mathieson G. Dementia in Parkinson disease: a neuropathologic study. Neurology 1979; 29: 1209-1214.

23. Boller F, Mizutani T, Roessmann U, et al. Parkinson's disease, dementia and Alzheimer's disease: clinicopathological correlations. Ann Neurol 1980; 7: 329-335.

24. Rosenblum WI, Ghatak NR. Lewy bodies in the presence of Alzheimer's disease. Arch Neurol 1979; 36: 170-171.

25. Gaspar P, Gray F. Dementia in idiopathic Parkinson's disease: A neuropathological study of 32 cases. Acta Neuropathol (Berl) 1984; 64: 43-52.

26. Leverenz J, Sumi SM. Prevalence of Parkinson's disease in patients with Alzheimer's disease. (Abstract) Neurology 1984; 34 (Suppl 1): 101 .

27. Mann DMA, Yates PO. Pathological basis for neurotransmitter changes in Parkinson's disease. Neuropathol Appl Neurobiol 1983; 9: 3-19.

28. Ball MJ. The morphological basis of dementia in Parkinson's disease. Can J Neurol Sci 1984; 11: 180-184.

29. Tagliavini F, Pilleri G, Bouras C, et al. The basal nucleus of Meynert in idiopathic Parkinson's disease. Acta Neurol Scand 1984; 70: 20-28.

30. Ruberg M, Ploska A, Javoy-Agid F, et al. Muscarinic binding and choline acetyltransferase activity in parkinsonian subjects with reference to dementia. Brain Res 1982; 232: 129-139.

31. Dubois B, Ruberg M, Javoy-Agid F, et al. A subcortico-cortical cholinergic system is affected in Parkinson's disease. Brain Res 1983; 288: 213-218

32. Perry RH, Tomlinson BE, Candy JM, et al. Cortical cholinergic deficit in mentally impaired Parkinsonian patients (letter). Lancet $1983 ; 2: 789-790$.

33. Candy JM, Perry RH, Perry EK, et al. Pathological changes in the nucleus of Meynert in Alzheimer's and Parkinson's disease. J Neurol Sci 1983; 59: 277-289.

34. Arendt T, Bigl V, Arendt A, et al. Loss of neurons in the nucleus basalis of Meynert in Alzheimer's disease, paralysis agitans, and Korsakoff's disease. Acta Neuropathol (Berl) 1983; 61: 101-108.

35. Whitehouse PJ, Hedreen JC, White CL III, et al. Basal forebrain neurons in the dementia of Parkinson disease. Ann Neurol 1983; 13: $243-248$

36. Hornykiewicz O, Kish SJ. Neurochemical basis of dementia in Parkinson's disease. Can J neurol Sci 1984; 11: 185-190.

37. Nakano I, Hirano A. Parkinson's disease: Neuron loss in the nucleus basalis without concomitant Alzheimer's disease. Ann Neurol 1984; 15: 415-418.

38. Adams RD, Victor M. Principles of Neurology. Third edition. New York: McGraw-Hill 1985: 866-867.

39. Seitelberger F, Gross H, Pilz P. Pick's disease: A neuropathologic study. In: Hirano A, Miyoshi K, eds. Neuropsychiatric Disorders in the Elderly. New York: Igaku-Shoin 1981: 87-117.

40. Joachim CL, Morris JH, Schoene WC. Neuropathological findings in six cases of dementia with severe focal atrophy. (Abstract) J Neuropathol Exp Neurol 1986; 45: 361 .

41. Uhl GR, Hilt DC, Hedreen JC, et al. Pick's disease (lobar sclerosis): Depletion of neurons in the nucleus basalis of Meynert. Neurology 1983; 33: 1470-1473.

42. Munoz-Garcia D, Ludwin SK. Classical and generalised variants of Pick's disease. A clinicopathological, ultrastructural, and immunocytochemical comparative study. Ann Neurol 1984; 16: 467-480.

43. Yates CM, Simpson J, Maloney AFJ, et al. Neurochemical observations in a case of Pick's disease. J Neurol Sci 1980;48: 257-263.

44. Wood PL, Etienne P, Lal S, et al. A post-mortem comparison of the cortical cholinergic system in Alzheimer's disease and Pick's disease. J Neurol Sci 1983; 62: 211-217.

45. Tagliavini F, Pilleri G. Basal nucleus of Meynert. A neuropathological study in Alzheimer's disease, simple senile dementia. Pick's disease, and Huntington's chorea. J Neurol Sci 1983; 62: 243-260.

46. Case Records of the Massachusetts General Hospital (Case 16-1986). N Engl J Med 1986; 314: 1101-1111.

47. Hart MN, Cancilla PA, Frommes S, et al. Anterior horn cell degeneration and Bunina-type inclusions associated with dementia. Acta Neuropathol (Berl) 1977; 38: 225-228.

48. Hudson A. Amyotrophic lateral sclerosis and its association with dementia, Parkinsonism and other neurological disorders: A review. Brain 1981; 104: 217-247.

49. Horoupian DS, Thal L, Katzman R, et al. Dementia and motor neuron disease: Morphometric, biochemical, and Golgi studies. Ann Neurol 1984; 16: 305-313.

50. Salazar A, Masters C, Gajdusek DC, et al. Syndromes of amyotrophic lateral sclerosis and dementia: Relation to transmissible Creutzfeldt-Jakob disease. Ann Neurol 1983; 14: 17-26.

51. Brion S, Mikol J, Psimaras A. Recent findings in Pick's disease. In: Zimmerman HM, ed. Progress in Neuropathology, vol. 2. New York: Grune \& Stratton, 1973; 421-452.

52. Brion S, Psimaras A, Chevalier JF, et al. L'association maladie de Pick et sclerose laterale amyotrophique. L'Encephale 1980; 6: 259-286.

53. Mitsuyama Y, Takamiya S. Presenile dementia with motor neuron disease in Japan: a new entity. Arch Neurol 1979; 36: 592-593.

54. Mitsuyama Y. Presenile dementia with motor neuron disease in Japan: Clinicopathological review of 26 cases. J Neurol Neurosurg Psychiat 1984; 47: 953-959.

55. Hughes CP, Myers FK, Smith K, et al. Nosologic problems in dementia: A clinical and pathologic study of 11 cases. Neurology 1973; 23: 344-351.

56. Rogers JD, Brogan D, Mirra SS. The nucleus basalis of Meynert in neurological disease. A quantitative morphological study. Ann Neurol 1985; 17: 163-171.

57. Okazaki H, Reagan TJ, Campbell RJ. Clinicopathologic studies of primary cerebral amyloid angiopathy. Mayo Clin Proc 1979; 54: 22-31.

58. Mandybur T1. Cerebral amyloid angiopathy: The vascular pathology and complications. J Neuropathol Exp Neurol 1986; 45: 79-90.

59. Daniel SE, Love S, Scaravilli F, et al. Encephalomyeloneuropathy in the absence of a detectable neoplasm: Clinical and postmortem findings in three cases. Acta Neuropathol (Berl) 1985; 66: 311-317.

60. Duyckaerts C, Derouesne C, Signoret JL, et al. Bilateral and limited amygdalohippocampal lesions causing a pure amnesic syndrome. Ann Neurol 1985; 18: 314-319.

61. Henson RA, Urich H. Encephalomyelitis with carcinoma. In: Henson RA, Urich H. Cancer and the Nervous System. London: Blackwell 1982; 314-345.

62. Brierley JB, Corsellis JAN, Hierons R, et al. Subacute encephalitis of later adult life mainly affecting the limbic areas. Brain 1960; 83: 357-368.

63. Case Records of the Massachusetts General Hospital (Case 30-1985). N Engl J Med 1985; 313: 249-257.

64. Schubert T, Friede RL. Transneuronal mammillary atrophy. J Neurol 1979;221: 67-72.

65. Volpe BT, Petito CK. Dementia with bilateral medial temporal lobe ischemia. Neurology 1985; 35: 1793-1797.

66. Heffner RR, Porro RS, Olson ME, et al. A demyelinating disorder associated with cerebrovascular amyloid angiopathy. Arch Neurol 1976; 33: 501-506.

67. Feigin I, Popoff N. Neuropathological changes late in cerebral edema: The relationship to trauma, hypertensive disease and Binswanger encephalopathy. J Neuropathol Exp Neurol 1963; 22: 500-511.

68. Martin JJ. Thalamic degenerations. In: Vinken PJ, Bruyn GW, eds. Handbook of Clinical Neurology, vol. 21. New York: Elsevier $1975 ;$ 587-604.

69. Neumann MA, Cohn R. Progressive subcortical gliosis, a rare form of presenile dementia. Brain 1967; 90: 405-418.

70. Davis PH, Bergeron C, McLachlan DR. Atypical presentation of progressive supranuclear palsy. Ann Neurol 1985; 17: 337-343.

71. Brown P. Johnson PR, Cathala F, et al. Creutzfeldt-Jakob disease 
of long duration: Clinicopathological characteristics, transmissibility, and differential diagnosis. Ann Neurol 1984; 16: 295-304.

72. Mirra SS, Anand R, Spira TJ. HTLV-III/LAV infection of the central nervous system in a 57 -year-old man with progressive dementia of unknown cause. (Letter) N Engl J Med 1986; 314 : 1191.1192.

73. Fuld PA, Katzman R, Davies P, et al. Intrusion as a sign of Alzheimer dementia: Chemical and pathological verification. Ann Neurol 1982; 11: 155-159.

74. Tune L, Gucker S, Folstein M, et al. Cerebrospinal fluid acetylcholinesterase activity in senile dementia of Alzheimer type. Ann Neurol 1985; 17: 46-48.

75. Jagust WJ, Friedland RP, Budinger TF. Positron emission tomography with ${ }^{18} \mathrm{~F}$ Fluorodeoxyglucose differentiates normal pressure hydrocephalus from Alzheimer-type dementia. J Neurol Neurosurg
Psychiat 1985; 48: $1091-1096$.

76. Neumann MA, Cohn R. Degenerative cerebral diseases and their relation to aging. In: Proceedings of the VIIth International Congress of Neuropathology. Amsterdam: Excerpta Medica 1975: 75-78.

77. Tomlinson BE, Blessed G, Roth M. Observations on the brains of non-demented old people. J Neurol Sci 1968; 7: 331-356.

78. Tomlinson BE, Blessed G, Roth M. Observations on the brains of demented old people. J Neurol Sci 1970; 11: 205-242.

79. Perl DP, Pendlebury WW, Bird ED. Detailed neuropathologic evaluation of banked brain specimens submitted with a clinical diagnosis of Alzheimer's disease (Abstract). In: Wurtman RJ, Corkin SH, Growdon JH, eds. Proceedings of the Third Meeting of the International Study Group on the Treatment of Memory Disorder Associated with Aging. Center for Brain Sciences and Metabolism Charitable Trust 1984; 463. 